\title{
Article \\ Thyroidectomy for Cancer: The Surgeon and the Parathyroid Glands Sparing
}

\author{
Giuliano Perigli ${ }^{1}$, Fabio Cianchi ${ }^{1}{ }^{\complement}$, Francesco Giudici ${ }^{1, *}{ }^{\mathbb{D}}$, Edda Russo ${ }^{1} \mathbb{D}$, Giulia Fiorenza ${ }^{1}$, Luisa Petrone ${ }^{2}$, \\ Clotilde Sparano ${ }^{2}$, Fabio Staderini ${ }^{1} \mathbb{D}$, Benedetta Badii ${ }^{1}$ and Alessio Morandi ${ }^{1}$
}

1 Department of Experimental and Clinical Medicine, University of Florence, Largo Brambilla, 6, 50135 Florence, Italy; giuliano.perigli@unifi.it (G.P.); fabio.cianchi@unifi.it (F.C.); edda.russo@unifi.it (E.R.); giulia.fiorenza@yahoo.it (G.F.); fabio.staderini@unifi.it (F.S.); benedettabadii@yahoo.it (B.B.); morandialessio9@gmail.com (A.M.)

2 Department of Biomedical, Experimental and Clinical Sciences Mario Serio, University of Florence, Largo Brambilla, 6, 50135 Florence, Italy; luisa.petrone@unifi.it (L.P.); clotilde.sparano@unifi.it (C.S.)

* Correspondence: francesco.giudici@unifi.it

check for updates

Citation: Perigli, G.; Cianchi, F.; Giudici, F.; Russo, E.; Fiorenza, G.; Petrone, L.; Sparano, C.; Staderini, F.; Badii, B.; Morandi, A. Thyroidectomy for Cancer: The Surgeon and the Parathyroid Glands Sparing. J. Clin. Med. 2021, 10, 4323. https://doi.org/ $10.3390 /$ jcm10194323

Academic Editors: Giovanni Vitale and Giovanni Conzo

Received: 21 July 2021

Accepted: 18 September 2021

Published: 23 September 2021

Publisher's Note: MDPI stays neutral with regard to jurisdictional claims in published maps and institutional affiliations.

Copyright: (c) 2021 by the authors. Licensee MDPI, Basel, Switzerland. This article is an open access article distributed under the terms and conditions of the Creative Commons Attribution (CC BY) license (https:// creativecommons.org/licenses/by/ $4.0 /)$.
Abstract: Background: The diagnosis of thyroid cancer is continuously increasing and consequently the amount of thyroidectomy. Notwithstanding the actual surgical skill, postoperative hypoparathyroidism still represents its most frequent complication. The aims of the present study are to analyze the rate of postoperative hypoparathyroidism after thyroidectomy, performed for cancer by a single first operator, without any technological aid, and to compare the data to those obtained adopting the most recent technological adjuncts developed to reduce the postoperative hypoparathyroidism. Methods: During the period 1997-2020 at the Endocrine Surgery Unit of the Department of Clinical and Experimental Medicine of the University of Florence, 1648 consecutive extracapsular thyroidectomies for cancer (401 with central compartment node dissection) were performed. The percentage of hypoparathyroidism, temporary or permanent, was recorded both in the first period (Group A) and in the second, most recent period (Group B). Total thyroidectomies were compared either with those with central compartment dissection and lobectomies. Minimally invasive procedures (MIT, MIVAT, some transoral) were also compared with conventional. Fisher's exact and Chi-square tests were used for comparison of categorical variables. $p<0.01$ was considered statistically significant. Furthermore, a literature research from PubMed ${ }^{\circledR}$ has been performed, considering the most available tools to better identify parathyroid glands during thyroidectomy, in order to reduce the postoperative hypoparathyroidism. We grouped and analyzed them by technological affinity. Results: On the 1648 thyroidectomies enrolled for the study, the histotype was differentiated in $93.93 \%$ of cases, medullary in $4 \%$ and poorly differentiated in the remaining $2.06 \%$. Total extracapsular thyroidectomy and lobectomy were performed respectively in $95.45 \%$ and $4.55 \%$. We recorded a total of $318(19.29 \%)$ cases of hypocalcemia, with permanent hypoparathyroidism in $11(0.66 \%)$. In regard to the literature, four categories of tools to facilitate the identification of the parathyroids were identified: (a) vital dye; (b) optical devices; (c) autofluorescence of parathyroids; and (d) autofluorescence enhanced by contrast media. Postoperative hypoparathyroidism had a variable range in the different groups. Conclusions: Our data confirm that the incidence of post-surgical hypoparathyroidism is extremely low in the high volume centers. Its potential reduction adopting technological adjuncts is difficult to estimate, and their cost, together with complexity of application, do not allow immediate routine use. The trend towards increasingly unilateral surgery in thyroid carcinoma, as confirmed by our results in case of lobectomy, is expected to really contribute to a further reduction of postsurgical hypoparathyroidism.

Keywords: thyroid carcinoma; postoperative complications; hypoparathyrodism; hypocalcemia; parathyroid glands; methylene bleu; optical devices; autofluorescence; indocyanine green 


\section{Introduction}

The incidence of thyroid carcinoma has more than tripled in recent decades and consequently so have thyroidectomies and their related complications [1,2]. It has long been known that the most frequent of these is postoperative hypocalcaemia from temporary or permanent parathyroid insufficiency due to unavoidable, involuntary removal, thermal or vascular damage of the parathyroids. The incidence increases if total thyroidectomy is associated with central compartment lymph-node dissection, when parathyroid glands are often accidentally or inevitably removed in the pursuit of oncological radicality $[3,4]$. The temporary form is still frequent and the permanent form is problematic to treat due to the potential negative aspects of prolonged administration of calcium and vitamin D and the unavailability of a replacement hormone $[5,6]$. Considering earlier diagnosis with smaller size of thyroid carcinoma, the most recent guidelines point towards less aggressive and often unilateral surgical treatment [1-7]. The expected reduction in hypoparathyroidism is not substantial. In fact, total thyroidectomy remains by far the most prevalent intervention due to the presence of concomitant contralateral nodularity or hormonal hyperfunction [8]. Moreover, even in lesions with indication for radiometabolic therapeutic completion, surgical radicality should always be pursued to avoid potential interferences in the humoral and instrumental follow-up of a parenchymal residual. Although hypoparathyroidism is the most common complication after thyroidectomy, the literature reports extremely different incidence and prevalence values, ranging from $1.6 \%$ to more than $50 \%$. In literature, the adoption of non-univocal and non-standardized parameters in reporting postoperative complications determines the inclusion in the different case series of very heterogeneous patients, symptomatic or asymptomatic, with mild or severe hypocalcaemia [9-11]. Especially in the case of permanent hypoparathyroidism, which worsens the quality of life due to replacement therapy and undefined controls, the differences are even more marked if one compares the case histories of dedicated surgical centres, general centres and general epidemiological surveys including patients who have escaped specialist controls. In fact, contrary to what has been estimated, the majority of the studies report hypoparathyroidism with percentages of more than $10 \%$, even though these are often mild forms that can be easily controlled with low doses of calcium and vitamin $\mathrm{D}$, which rarely expose the patient to complications such as calcification of the extra-skeletal soft tissues, basal ganglia and kidney, as observed in cases that require much higher doses to compensate for the almost total lack of parathyroid hormone [12-18].

In the face of these unexpected rates of post-surgical hypoparathyroidism revealed by the most recent studies, it is not surprising that surgeons have turned to testing every means of reducing them. In fact, it no longer seemed sufficient to rely solely on the recommendations of good surgical practice and the individual surgeon's experience and ability to detect them with the naked eye aided only by good lighting and optional optical magnification as basically indicated by the most authoritative guidelines [1].

The present paper, with a mainly clinical focus, has two aims: (a) to analyze the rate of postoperative hypoparathyroidism after thyroidectomy performed for cancer by a single first operator without any technological aid; (b) to evaluate if the numerous technological proposals that have emerged in recent years in an attempt to make objective identification of the parathyroids and assessment of their function, overcoming the limits related to the subjective judgement of the individual surgeon, are really useful in reducing the postoperative hypoparathyroidism incidence.

\section{Materials and Methods}

During the period 1997-2020 at the Endocrine Surgery Unit of the Department of Clinical and Experimental Medicine of the University of Florence, 1648 consecutive extracapsular thyroidectomies for cancer (401 with central compartment node dissection) were performed, and the patients' data prospectively recorded in an electronic database. A prospective study was conducted after approval by the Area Vasta Regione Toscana/AOUC Ethics Committee (N 20534). An informed written consent was obtained from each patient. 
For the follow-up we have collaborated with the Endocrinology Unit of the same institution with which this activity has been constantly shared.

These are 1648 consecutive thyroidectomies, in 401 patients with central compartment lymph node dissection, to treat thyroid carcinoma performed almost exclusively by one of the authors (GP) in little more than 20 years and in small part $(<10 \%)$ by collaborators always in his presence.

The case series was divided into a first period (March 1997-April 2015) (Group A) and a second period (May 2015-December 2020) (Group B), each consisting of 824 consecutive cases. No technological adjunct was adopted in both periods. The thyroidectomy procedure, always extracapsular, was carried out with the naked eye without magnifying glasses or frontal light but only with the operating light.

In addition to demographic data, the percentages of hypoparathyroidism (symptomatic or asymptomatic), temporary or definitive, were recorded calcium and PTH values, tested preoperatively, and at $12,18 \mathrm{~h}$ and 7 days postoperatively lower than normal (respectively $8.5 \mathrm{mg} / \mathrm{dL}$ and $1.5 \mathrm{pmol} / \mathrm{L}$ in our laboratory) and the need for calcium-vitamin D replacement therapy over six months after surgery for the definitive form.

We also included the 75 lobectomies in which the central compartment had been explored and compared with total extracapsular thyroidectomies.

Total thyroidectomies were compared with those with central compartment and laterocervical lymph-adenectomy (in which we systematically also performed the central dissection); minimally invasive procedures (MIT, MIVAT, some transoral) with conventional ones and the first period of the series with the second one.

For the statistical analysis, Chi-square tests or Fisher's exact, when appropriate, and were used for comparison of categorical variables. $p<0.01$ was considered statistically significant.

From the literature published in Pub Med ${ }^{\circledR}$ in recent years, we extracted the most suitable experiments to represent the current means available for a better identification of the parathyroid glands during thyroidectomy. We grouped them by technological affinity. The most reliable in terms of potential immediate clinical use experiments were critically revised.

\section{Results}

\subsection{Our Experience}

On 5264 thyroidectomies performed from January 1997 to December 2020, we enrolled all the 1648 patients who had undergone thyroidectomy for carcinoma. The histotype was differentiated in $93.93 \%$ of cases, medullary in $4 \%$ and poorly differentiated in the remaining $2.06 \%$.

In $95.45 \%$ of the cases total extracapsular glandular excisions were performed and in $4.55 \%$ lobectomy alone was considered oncologically sufficient after negative exploration of the central compartment.

We recorded a total of 318 hypocalcemia $(19.29 \%)$ of which $11(0.66 \%)$ diagnosed as permanent hypoparathyroidism requiring therapy for more than 6 months. In particular, we found that hypocalcemia affected 316 patients after total thyroidectomy $(20.09 \%)$, and only 2 patients after lobectomy (2.66\%); after total thyroidectomy, 202 patients $(25.06 \%)$ had hypocalcemia in Period A and $114(14.86 \%)$ in Period B $(p<0.0001)$, while no patient in Period A and 2 patients $(3.51 \%)$ in Period B suffered this complication after lobectomy $(p<0.0001)$.

Clinical characteristics of patients are described in Figure 1 and Table 1. 


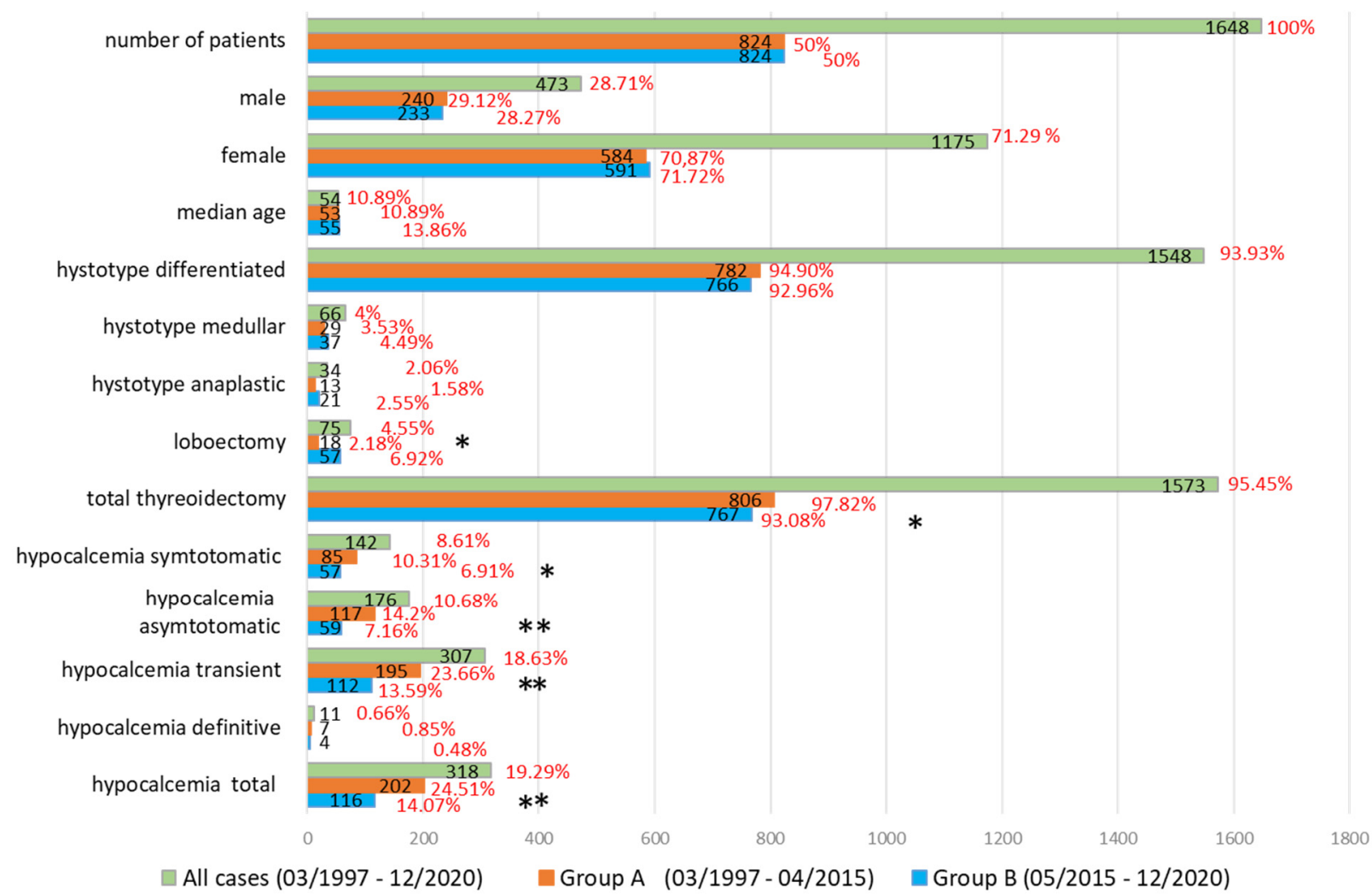

Figure 1. Demographic characteristics of the patients, type of operation and histotype of malignancy, incidences of temporary and permanent hypocalcaemia in the total case series and in the first and second period. Black numbers indicate the number of patients, while red numbers indicate the percentage. Differences between the groups were calculated via the Chi Square, or Fisher's exact test, when appropriate (both 2-tailed); a $p<0.01$ is considered statistically significant. ${ }^{*} p<0.01,{ }^{* *} p<0.0001$.

Table 1. Comparison of conventional and minimally invasive procedures and of patients who received only a total thyroidectomy versus those in whom a central compartment lymphectomy was also performed, whether or not extended to the lateral compartments.

\begin{tabular}{|c|c|c|c|c|c|c|c|c|c|c|c|}
\hline & & & p A & & p B & \multirow{4}{*}{$\stackrel{p}{p}$} & $\mathrm{Gr}$ & $\mathbf{A}$ & & & \multirow{4}{*}{$p$ Value } \\
\hline \multicolumn{2}{|c|}{ Type of Surgery } & \multicolumn{4}{|c|}{ Minimally Invasive } & & & Conv & onal & & \\
\hline \multicolumn{2}{|c|}{ cases } & \multicolumn{2}{|c|}{403} & \multicolumn{2}{|c|}{257} & & \multicolumn{2}{|c|}{421} & \multicolumn{2}{|c|}{567} & \\
\hline & & $N$ & $\%$ & $N$ & $\%$ & & $N$. & $\%$ & $N$ & $\%$ & \\
\hline \multirow{5}{*}{ hypocalcemia } & symptomatic & 38 & 9.43 & 14 & 5.44 & 0.0752 & 47 & 11.16 & 43 & 7.58 & 0.0577 \\
\hline & asymptomatic & 56 & 13.89 & 24 & 9.34 & 0.0875 & 61 & 14.49 & 35 & 6.17 & $<0.0001$ \\
\hline & transient & 91 & 22.58 & 37 & 14.39 & 0.01 & 104 & 24.7 & 76 & 13.4 & $<0.0001$ \\
\hline & definitive & 3 & 0.74 & 1 & 0.39 & 1 & 4 & 0.95 & 2 & 0.35 & 0.4106 \\
\hline & total & 94 & 23.32 & 38 & 14.78 & 0.003 & 108 & 25.65 & 78 & 13.75 & $<0.0001$ \\
\hline \multicolumn{2}{|c|}{ Type of Surgery } & \multicolumn{4}{|c|}{ Cclnd } & \multicolumn{6}{|c|}{ No Cclnd } \\
\hline \multicolumn{2}{|c|}{ cases } & \multicolumn{2}{|c|}{216} & \multicolumn{2}{|c|}{185} & & \multicolumn{2}{|c|}{608} & \multicolumn{2}{|c|}{639} & \\
\hline & & $N$. & $\%$ & $N$. & $\%$ & & $N$. & $\%$ & $N$. & $\%$ & \\
\hline \multirow{5}{*}{ hypocalcemia } & symptomatic & 44 & 20.37 & 32 & 17.29 & 0.4464 & 45 & 7.4 & 28 & 4.38 & 0.0293 \\
\hline & asymptomatic & 40 & 18.51 & 29 & 15.68 & 0.5077 & 73 & 12.01 & 27 & 4.22 & $<0.0001$ \\
\hline & transient & 79 & 36.57 & 59 & 31.89 & 0.3 & 116 & 19.08 & 53 & 8.29 & $<0.0001$ \\
\hline & definitive & 5 & 2.31 & 2 & 1.08 & 0.4589 & 2 & 0.33 & 2 & 0.31 & 1 \\
\hline & total & 84 & 38.88 & 61 & 32.97 & 0.2 & 118 & 19.41 & 55 & 8.6 & $<0.0001$ \\
\hline
\end{tabular}

Abbreviations: cclnd, central compartment lymph node dissection. Differences between the groups were calculated via the Chi Square, or Fisher's exact test, when appropriate (both two-tailed); a $p<0.01$ is considered statistically significant. 


\subsection{Literature Examination}

The literature reports four categories of tools that can be used by the surgeon, together with his eyes and experience, to facilitate the identification of the parathyroids (Table 2):

(a) Vital dye such as methylene bleu [19-21].

(b) Optical devices without contrast media and unaffected by ambient light [22-26].

(c) Autofluorescence of parathyroids detected by infrared light or laser stimulation [27-33].

(d) Autofluorescence enhanced by injection of indocyanine green or 5-ALA [34,35].

Table 2. The main original studies evaluating technologies in order to avoid postoperative hypoparathyroidism, from 1971 to 2021.

\begin{tabular}{|c|c|c|c|c|c|c|}
\hline Reference & Technology & Article Type & $\mathrm{Nb}$ pt & $\begin{array}{l}\text { Parathyroid } \\
\text { Identification }\end{array}$ & $\begin{array}{l}\text { Postoperative } \\
\text { Hypo-PTH } \\
\text { /Hypoca }\end{array}$ & Conclusions \\
\hline $\begin{array}{c}\text { Dudley } \\
\text { et al. [19] } 1971\end{array}$ & $\begin{array}{l}\text { Intravenous } \\
\text { infusion of } \\
\text { methylene blue }\end{array}$ & original/humans & 17 & $41 / 68$ & / & $\begin{array}{l}\text { Could help to reduce } \\
\text { the high } \\
\text { incidence of clinical } \\
\text { hypoparathyroidism } \\
\text { after total } \\
\text { thyroidectomy. }\end{array}$ \\
\hline $\begin{array}{l}\text { Monib } \\
\text { et al. [20] } 2020\end{array}$ & $\begin{array}{l}\text { Intraoperative } \\
\text { methylene } \\
\text { blue spray }\end{array}$ & original/humans & 50 & $82 \%$ accuracy & $18 \%$ & $\begin{array}{l}\text { Safe, feasible, and } \\
\text { effective to identify } \\
\text { parathyroid glands }\end{array}$ \\
\hline $\begin{array}{l}\text { Sari et al. [21] } \\
\qquad 2012\end{array}$ & $\begin{array}{l}\text { Intraoperative } \\
\text { methylene } \\
\text { blue spray }\end{array}$ & original/humans & 56 & / & $5 \%$ transient & $\begin{array}{c}\text { Identification of } \\
\text { parathyroid glands } \\
\text { within three minutes } \\
\text { and also of recurrent } \\
\text { laryngeal nerves } \\
\text { and inferior } \\
\text { thyroid arteries. }\end{array}$ \\
\hline $\begin{array}{l}\text { Hu et al. [22] } \\
2021\end{array}$ & $\begin{array}{c}\text { Dynamic optical } \\
\text { contrast imaging } \\
(\mathrm{DOCI})\end{array}$ & $\begin{array}{l}\text { original/animals } \\
\text { and humans } \\
\text { ex vivo }\end{array}$ & / & / & / & $\begin{array}{l}\text { Facilitates specific } \\
\text { parathyroid } \\
\text { gland localization }\end{array}$ \\
\hline $\begin{array}{c}\text { Marsden } \\
\text { et al. [23] } 2021\end{array}$ & $\begin{array}{c}\text { Fluorescence } \\
\text { lifetime imaging } \\
\text { (FLIm) }\end{array}$ & original/humans & 21 & $\begin{array}{c}100 \% \\
\text { sensitivity } \\
93 \% \\
\text { specificity }\end{array}$ & / & $\begin{array}{l}\text { Good sensitivity and } \\
\text { specificity for the rapid } \\
\text { identification of PG. }\end{array}$ \\
\hline $\begin{array}{c}\text { Mannoh } \\
\text { et al. [24] } 2021\end{array}$ & $\begin{array}{c}\text { Laser speckle } \\
\text { contrast imaging } \\
(\mathrm{LSCI})\end{array}$ & original/humans & 72 & / & $\begin{array}{l}8.3 \% \text { temporary } \\
1.4 \% \text { permanent }\end{array}$ & $\begin{array}{l}\text { Promising technique } \\
\text { for assessing } \\
\text { parathyroid } \\
\text { gland vascularity }\end{array}$ \\
\hline $\begin{array}{l}\text { Kennedy et al. } \\
2021 \text { [25] }\end{array}$ & $\begin{array}{l}\text { Near-infrared } \\
\text { molecular Imaging } \\
\text { (IMI) }\end{array}$ & original/humans & 5 & $9 / 9$ & $\begin{array}{c}1 / 9 \\
\text { asymptomatic }\end{array}$ & $\begin{array}{l}\text { Accurate and } \\
\text { reproducible method } \\
\text { of localizing } \\
\text { parathyroid glands }\end{array}$ \\
\hline $\begin{array}{l}\text { Wang et al. [26] } \\
2021\end{array}$ & $\begin{array}{c}\text { Laser-induced } \\
\text { breakdown } \\
\text { spectroscopy (LIBS) }\end{array}$ & $\begin{array}{l}\text { original/animals } \\
\text { ex vivo }\end{array}$ & / & / & / & $\begin{array}{l}\text { Can discriminate } \\
\text { between smear } \\
\text { samples of PG } \\
\text { and NPG }\end{array}$ \\
\hline $\begin{array}{l}\text { Paras et al. [27] } \\
2011\end{array}$ & $\begin{array}{l}\text { Near-infrared (NIR) } \\
\text { autofluorescence }\end{array}$ & original/humans & 21 & / & / & $\begin{array}{l}\text { Parathyroid } \\
\text { fluorescence was two } \\
\text { to eleven times higher } \\
\text { than that of the thyroid } \\
\text { tissues with peak } \\
\text { fluorescence occurring } \\
\text { at } 820 \text { to } 830 \mathrm{~nm} \text {. }\end{array}$ \\
\hline
\end{tabular}


Table 2. Cont.

\begin{tabular}{|c|c|c|c|c|c|c|}
\hline Reference & Technology & Article Type & $\mathrm{Nb}$ pt & $\begin{array}{l}\text { Parathyroid } \\
\text { Identification }\end{array}$ & $\begin{array}{l}\text { Postoperative } \\
\text { Hypo-PTH } \\
\text { /Hypoca }\end{array}$ & Conclusions \\
\hline $\begin{array}{c}\text { Aoyama } \\
\text { et al. [28] } 2020\end{array}$ & $\begin{array}{l}\text { Near-infrared (NIR) } \\
\text { autofluorescence }\end{array}$ & original/humans & 2 & / & / & $\begin{array}{l}\text { The autofluorescence } \\
\text { of diseased glands was } \\
\text { weaker than that of } \\
\text { normal glands, even } \\
\text { with the excitation } \\
\text { light of NIR. }\end{array}$ \\
\hline $\begin{array}{c}\text { Akbulut } \\
\text { et al. [29] } 2021\end{array}$ & $\begin{array}{l}\text { Near-infrared (NIR) } \\
\text { autofluorescence }\end{array}$ & original/humans & 300 & $25 \%$ * & / & $\begin{array}{l}\text { Second-generation } \\
\text { NIFI (CMOS) } \\
\text { displayed higher } \\
\text { detection rates and } \\
\text { AF intensity. }\end{array}$ \\
\hline $\begin{array}{l}\text { Kim et al. [30] } \\
2021\end{array}$ & $\begin{array}{l}\text { Near-infrared (NIR) } \\
\text { autofluorescence }\end{array}$ & original/humans & 542 & / & $\begin{array}{c}4.2 \% \\
\text { permanent }\end{array}$ & $\begin{array}{l}\text { May reduce temporary } \\
\text { hypoparathyroidism } \\
\text { and the risk of } \\
\text { inadvertent resection } \\
\text { of PGs in CND. }\end{array}$ \\
\hline $\begin{array}{c}\text { Wiseman } \\
\text { et al. [31] } 2021\end{array}$ & $\begin{array}{l}\text { Near-infrared (NIR) } \\
\text { autofluorescence }\end{array}$ & $\begin{array}{c}\text { original/humans } \\
\text { in vivo and ex } \\
\text { vivo }\end{array}$ & / & / & / & $\begin{array}{c}\text { Can successfully } \\
\text { intraoperatively } \\
\text { identify both normal } \\
\text { and pathological PGs. }\end{array}$ \\
\hline $\begin{array}{c}\text { Kiernan } \\
\text { et al. [32] } 2021\end{array}$ & $\begin{array}{l}\text { Near-infrared (NIR) } \\
\text { autofluorescence }\end{array}$ & original/humans & 83 & $\begin{array}{c}94.3 \% \\
\text { accuracy }\end{array}$ & / & $\begin{array}{l}\text { Probe-based NIRAF } \\
\text { detection can be a } \\
\text { valuable adjunct device } \\
\text { to intraoperatively } \\
\text { identify PGs. }\end{array}$ \\
\hline $\begin{array}{c}\text { Mannoh } \\
\text { et al. [33] } 2021\end{array}$ & $\begin{array}{l}\text { ParaSPAI a device } \\
\text { that combines } \\
\text { NIRAF imaging } \\
\text { with LSCI }\end{array}$ & original/humans & / & / & / & $\begin{array}{l}\text { Capable of label-free } \\
\text { parathyroid gland } \\
\text { identification and } \\
\text { vascularity assessment } \\
\text { through the } \\
\text { combination of NIRAF } \\
\text { imaging with LSCI. }\end{array}$ \\
\hline $\begin{array}{c}\text { Suzuki } \\
\text { et al. [34] } 2011\end{array}$ & $\begin{array}{c}\text { 5-Aminolevulinic } \\
\text { Acid }\end{array}$ & original/humans & 13 & $\begin{array}{l}\text { In all patients } \\
\text { at least one }\end{array}$ & / & $\begin{array}{l}\text { Useful to localize the } \\
\text { normal parathyroid } \\
\text { glands during } \\
\text { thyroid surgery }\end{array}$ \\
\hline $\begin{array}{c}\text { Jin et al. [35] } \\
2018\end{array}$ & Indocyanine green & original/humans & 26 & / & $7.69 \%$ transient & $\begin{array}{l}\text { Safe, easy and effective } \\
\text { method to protect the } \\
\text { parathyroid and } \\
\text { predict postoperative } \\
\text { hypoparathyroidism }\end{array}$ \\
\hline
\end{tabular}

Abbreviations: / = no available data. $\mathrm{Nb}$ pt $=$ number of patients; $\mathrm{PG}=$ parathyroid gland; NPG = no parathyroid gland; ${ }^{*}=$ before visual identification of PGs; NIFI = near-infrared fluorescence imaging; CMOS = complementary metal-oxide semiconductor; $\mathrm{AF}$ = autofluorescence; $\mathrm{CND}=$ central neck dissection; ParaSPAI = parathyroid speckle and autofluorescence imager; $\mathrm{LSCI}=$ laser speckle contrast imaging.

\section{Discussion}

The literature evaluation has enabled us to consolidate certain convictions developed over many years of activity. Firstly, the difficulty of defining hypoparathyroidism due to the variables that characterize it and the clinical manifestations that arise with serum calcium levels, which vary greatly in every single patient [1]. 
We agree with Sitges-Serra that it is inappropriate and reductive to categorize it clearly between clinical and humoral, temporary and definitive, since functional recovery is a dynamic process that can last up to two years [9].

We have noted a considerable discrepancy in the prevalence of post-surgical hypoparathyroidism, especially permanent, reported in the various case histories according to their origin. The ranges appear almost irreconcilable when comparing the surgical series with the endocrinological or epidemiological ones, and the most common values are around $1-3 \%$ in the former and around $12 \%$ in the latter $[3,8,10,15,36]$.

There is a unanimous agreement in the literature that the identification and functional preservation of the parathyroids is difficult due to the presence of contiguous similar structures such as thyroid nodules, lymph nodes, adipose lobules or fibrosis from previous operations. Therefore, it is directly related to the sensitivity and experience of the surgeon, even though he strictly adheres to the principles of good surgical practice, which, in addition to anatomical integrity and the number of glands identified, also recommend respect for vascular support $[1,37,38]$. Recent studies have in fact shown that accidental removal and tissue or vascular damage do not find a remedy in glands autotransplantation [9], and allografting is still not beyond the experimental stage or good hopes for the future [39]. There is evidence that systematic and meticulous research can lead to invisible parathyroids damage and that selective identification is preferable to routine identification. In fact, it would appear that the number of parathyroids actually left 'in situ' is more important than the number of those identified [8,40-43].

Regarding instruments potentially useful in reducing post-surgical hypocalcaemia through better identification and functional preservation of the parathyroids, intraoperative biopsy, rapid PTH dosage on aspirate [44-47] and gamma probe identification [48], which were proposed in the past and are now obsolete because they are invasive, costly, time-consuming and ethically inapplicable as they damage tissue that should ideally be preserved as much as possible, are now rarely used.

The simplest and easiest means of identifying vital parathyroids would be the use of methylene blue. Known for fifty years [19] and appreciated for the identification of pathological glands, it did not provide the same results in the recognition of normal glands during thyroidectomy when injected intravenously. The recent adoption of a spray application directly on the operating field seems to have achieved a high level of accuracy, even avoiding the problem of the potential toxicity [20,21,49].

Looking at the group of instruments based on optical technology such as DOCI (dynamic optical contrast imaging), FLIm (fluorescence lifetime imaging), LSCI (laser speckle contrast imaging), NIMI (near infrared molecular imaging), LIBS (laser induced breakdown spectroscopy), it is immediately evident that, despite the advantage of not using any contrast medium and not being influenced by ambient light, these are still experimental applications and reserved for research centres with strong financial backing, certainly not within the reach of most thyroid surgery centres [22-26,33]. They demonstrate a high level of accuracy in identifying and assessing glandular perfusion, but cannot prevent any iatrogenic damage produced during retrieval, which in any case precedes the test. Due to their complexity, they appear to be far from an imminent clinical application.

Paras et al. were the first in 2011 to discover and describe [27] an autofluorescence of the parathyroids induced by stimulation with high-energy light sources of endogenous fluorophores that reacted by emitting low-energy light. The exploitation of this property, apparently easier to apply and with potentially more immediate advantages, has offered a new opportunity in the attempt to reduce post-surgical hypoparathyroidism [27-33].

The long persistence of autofluorescence in parathyroids even after their removal makes this property unsuitable for perfusion assessment and has necessitated the injection of exogenous fluorophores as contrast agents or dyes (ICG, indocyanine green; 5-ALA, 5-aminolevulinic acid) to enhance natural fluorescence.

There are other commercially available laparoscopic or handheld camera instruments which, although designed for ICG study of other organ perfusion or sentinel node detection, 
can be used in parathyroid fluorescence detection. Even instruments combining two methods (Niraf and Laser-speckle contrast Imaging), Ref. [33] are not yet fully convincing and in any case not applicable on a large scale.

Solorzano et al., examined in detail all fluorescence-based technology applicable to parathyroid surgery today and compiled a valuable list of possible indications with potential advantages and disadvantages specific to probe-based and chamber-based technology.

Although the literature reports a sensitivity of autofluorescence of 80 to $100 \%$, it is also correctly acknowledged that there are false positives and negatives and that the main limitation of the method lies in its poor tissues penetration power and that it requires the manipulation of parathyroids, exposing to tissue damage. The additional use of ICG improves the power of identification and allows a judgement of perfusion that is not possible with autofluorescence alone. The conclusions are not definitive, so we invite others to further clarify its real cost-benefit [50].

To date, unfortunately only a few studies have demonstrated a direct correlation between visualization and glandular perfusion and a reduction in hypoparathyroidism [30], which is in any case limited to the temporary but not definitive form. Moreover, none of the prevention methods adopted seem to be able to reduce hypocalcaemia [42,49-55].

In summary, alongside with authoritative reviews confirming the feasibility and efficacy of recent parathyroid identification aids [56-58], there are others that urge caution in adopting them too enthusiastically before larger prospective and randomised studies confirm their superiority over surgeon volume and skill $[59,60]$. For example, the analysis of our case history, while showing values for temporary hypoparathyroidism that are in line with the literature (19.29\%), confirms the negligible values of our previous investigations $[4,8,18,61,62]$, for permanent hypoparathyroidism. The strict adoption of the specific principles of thyroid surgery required by the university didactic nature of our hospital and the high volume of cases treated, we believe, is sufficient to justify values much lower than those of other series but not too dissimilar from other Italian multicentric experiences where values of temporary and permanent hypoparathyroidism of $8.3 \%$ and $1.7 \%$ respectively are reported [3].

In this regard, the comparison between the first and second part of our series seems very expressive: although they are absolutely superimposable in terms of demographic characteristics and the methods adopted, they reveal statistically significant differences for both forms of hypoparathyroidism, confirming the well-known and recently reaffirmed [14] relationship between the surgeon's case-volume and the number of complications.

As expected, and as already noted in our previous experiences, the differences between minimally invasive and conventional surgery in the two groups are not significant [61,62].

In the second group, in accordance with the most recent guidelines, lobectomies increased but hypocalcaemia, which was never definitive, remained negligible, confirming that unilateral surgery, even in the cases we included with exploration of the central compartment, protects against hypocalcaemic complications.

On the other hand, the values are very different in both groups when comparing simple thyroidectomies and those accompanied by lymphectomy of the central compartment, respectively $19.41 \%$ vs. $38.8 \%$ in Group A and $8.61 \%$ vs. $32.97 \%$ in Group B. Interestingly, the percentages of hypoparathyroidism remained very similar in the two periods when total thyroidectomy was accompanied by central compartment lymphectomy, $38.88 \%$ in Group A and 32.97\% in Group B, respectively. Moreover, out of eleven patients with definitive hypoparathyroidism, as many as eight had undergone central compartment lymphectomy, demonstrating that the complication is strictly procedure-dependent and cannot be modified by the surgeon's experience.

In addition, this study also confirms the higher incidence of hypocalcaemia in simple total thyroidectomies for carcinoma compared with total thyroidectomies for benign disease, as previously reported by us and other authors (19.29\% vs. 12.99$),[4,8,14,63]$. However, a recent article from Onder CE et al., 2020, reports that the management of the patients with hypocalcaemia is suboptimal with active vitamin D and cholecalciferol treatment [64]. 
The limitation common to all the examined tools is that they only record what has already taken place and are not able to modify the intra-operative procedure except to indicate an autotransplant in the event of hypoperfusion, with the possibility to increase the risk of hypocalcaemia [9], therefore, the surgeon remains the one who has to assess the parathyroids site, shape, color (and its possible variations) or, by touch, their consistency.

\section{Conclusions}

Our findings show that post-surgical hypoparathyroidism is extremely uncommon in high-volume institutions. Its potential decrease through the employment of technical adjuncts is impossible to quantify, and their expense, combined with the complexity of their application, makes them unsuitable for immediate usage. As evidenced by our findings in the case of lobectomy, the trend toward more unilateral thyroid surgery is predicted to lead to a further reduction in postsurgical hypoparathyroidism.

Author Contributions: Conceptualization, G.P. and A.M.; methodology, E.R., C.S.; statistical analysis, E.R.; investigation, F.G., L.P., F.C., F.S., B.B., G.F. writing G.P., A.M., F.G., E.R.; editing, A.M., E.R.; supervision, G.P., F.G., F.C. All authors have read and agreed to the published version of the manuscript.

Funding: This research received no external funding.

Institutional Review Board Statement: The study was conducted according to the guidelines of the Declaration of Helsinki, and approved by the Area Vasta Regione Toscana/AOUC Ethics Committee (N 20534).

Informed Consent Statement: A written informed consent was obtained from each patient.

Acknowledgments: We thank Elisangela Miceli for the English revision.

Conflicts of Interest: The authors declare no conflict of interest.

\section{References}

1. Haugen, B.R.; Alexander, E.K.; Bible, K.C.; Doherty, G.M.; Mandel, S.J.; Nikiforov, Y.E.; Pacini, F.; Randolph, G.W.; Sawka, A.M.; Schlumberger, M.; et al. 2015 American Thyroid Association Management Guidelines for Adult Patients with Thyroid Nodules and Differentiated Thyroid Cancer: The American Thyroid Association Guidelines Task Force on Thyroid Nodules and Differentiated Thyroid Cancer. Thyroid 2016, 26, 1-133. [CrossRef] [PubMed]

2. Pellegriti, G.; Frasca, F.; Regalbuto, C.; Squatrito, S.; Vigneri, R. Worldwide increasing incidence of thyroid cancer: Update on epidemiology and risk factors. J. Cancer Epidemiol. 2013, 2013, 965212. [CrossRef] [PubMed]

3. Rosato, L.; Avenia, N.; Bernante, P.; De Palma, M.; Gulino, G.; Nasi, P.G.; Pelizzo, M.R.; Pezzullo, L. Complications of thyroid surgery: Analysis of a multicentric study on 14,934 patients operated on in Italy over 5 years. World J. Surg. 2004, 28, 271-276. [CrossRef]

4. Perigli, G.; Fiorenza, G.; Badii, B.; Skalamera, I.; Foppa, C.; Cianchi, F. Prevenzione e trattamento della ipocalcemia precoce e tardiva dopotiroidectomia. L'Endocrinologo 2018, 19, 6-9.

5. Bilezikian, J.P.; Brandi, M.L.; Cusano, N.E.; Mannstadt, M.; Rejnmark, L.; Rizzoli, R.; Rubin, M.R.; Winer, K.K.; Liberman, U.A.; Potts, J.T., Jr. Management of Hypoparathyroidism: Present and Future. J. Clin. Endocrinol. Metab. 2016, 101, 2313-2324. [CrossRef] [PubMed]

6. Allas, S.; Ovize, M.; Culler, M.D.; Geraul, C.; van de Wetering, J.; Mannstadt, M. A Single Administration of AZP-3601, a Novel, Long-Acting PTH Analog, Induces a Significant and Sustained Calcemic Response: Preliminary Data From a Randomized, Double-Blind, PlaceboControlled Phase 1 Study. J. Endocr. Soc. 2021, 5, A254. [CrossRef]

7. Tuttle, R.M. Controversial Issues in Thyroid Cancer Management. J. Nucl Med. 2018, 59, 1187-1194. [CrossRef] [PubMed]

8. Puzziello, A.; Rosato, L.; Innaro, N.; Orlando, G.; Avenia, N.; Perigli, G.; Calo, P.G.; De Palma, M. Hypocalcemia following thyroid surgery: Incidence and risk factors. A longitudinal multicenter study comprising 2631 patients. Endocrine 2014, 47, 537-542. [CrossRef] [PubMed]

9. Sitges-Serra, A. Etiology and Diagnosis of Permanent Hypoparathyroidism after Total Thyroidectomy. J. Clin. Med. 2021, 10, 543. [CrossRef]

10. Edafe, O.; Antakia, R.; Laskar, N.; Uttley, L.; Balasubramanian, S.P. Authors' reply: Systematic review and meta-analysis of predictors of post-thyroidectomy hypocalcaemia. Br. J. Surg 2014, 101, 883-884. [CrossRef]

11. Raffaelli, M.; De Crea, C.; D’Amato, G.; Moscato, U.; Bellantone, C.; Carrozza, C.; Lombardi, C.P. Post-thyroidectomy hypocalcemia is related to parathyroid dysfunction even in patients with normal parathyroid hormone concentrations early after surgery. Surgery 2016, 159, 78-84. [CrossRef] 
12. Pepe, J.; Colangelo, L.; Biamonte, F.; Sonato, C.; Danese, V.C.; Cecchetti, V.; Occhiuto, M.; Piazzolla, V.; De Martino, V.; Ferrone, F.; et al. Diagnosis and management of hypocalcemia. Endocrine 2020, 69, 485-495. [CrossRef] [PubMed]

13. Yazicioglu, M.O.; Yilmaz, A.; Kocaoz, S.; Ozcaglayan, R.; Parlak, O. Risks and prediction of postoperative hypoparathyroidism due to thyroid surgery. Sci. Rep. 2021, 11, 11876. [CrossRef]

14. Bedi, H.K.; Jedrzejko, N.; Nguyen, A.; Aspinall, S.R.; Wiseman, S.M. Thyroid and parathyroid surgeon case volume influences patient outcomes: A systematic review. Surg. Oncol. 2021, 38, 101550. [CrossRef]

15. Lui, D.T.W.; Fung, M.M.H.; Lee, C.H.; Fong, C.H.Y.; Woo, Y.C.; Lang, B.H.H. A territory-wide assessment of the incidence of persistent hypoparathyroidism after elective thyroid surgery and its impact on new fracture risk over time. Surgery 2021. [CrossRef]

16. Lorenz, K.; Raffaeli, M.; Barczynski, M.; Lorente-Poch, L.; Sancho, J. Volume, outcomes, and quality standards in thyroid surgery: An evidence-based analysis-European Society of Endocrine Surgeons (ESES) positional statement. Langenbecks Arch. Surg. 2020, 405, 401-425. [CrossRef] [PubMed]

17. Anneback, M.; Hedberg, J.; Almquist, M.; Stalberg, P.; Norlen, O. Risk of Permanent Hypoparathyroidism After Total Thyroidectomy for Benign Disease: A Nationwide Population-based Cohort Study From Sweden. Ann. Surg. 2020. [CrossRef] [PubMed]

18. Marcucci, G.; Cianferotti, L.; Parri, S.; Altieri, P.; Arvat, E.; Benvenga, S.; Betterle, C.; Bondanelli, M.; Boscaro, M.; Camozzi, V.; et al. HypoparaNet: A Database of Chronic Hypoparathyroidism Based on Expert Medical-Surgical Centers in Italy. Calcif. Tissue Int. 2018, 103, 151-163. [CrossRef] [PubMed]

19. Dudley, N.E. Methylene blue for rapid identification of the parathyroids. Br. Med. J. 1971, 3, 680-681. [CrossRef]

20. Monib, S.; Mohamed, A.; Abdelaziz, M.I. Methylene Blue Spray for Identification of Parathyroid Glands During Thyroidectomy. Cureus 2020, 12, e11569. [CrossRef]

21. Sari, S.; Aysan, E.; Muslumanoglu, M.; Ersoy, Y.E.; Bektasoglu, H.; Yardimci, E. Safe thyroidectomy with intraoperative methylene blue spraying. Thyroid Res. 2012, 5, 15. [CrossRef]

22. Hu, Y.; Han, A.Y.; Huang, S.; Pellionisz, P.; Alhiyari, Y.; Krane, J.F.; Shori, R.; Stafsudd, O.; St John, M.A. A Tool to Locate Parathyroid Glands Using Dynamic Optical Contrast Imaging. Laryngoscope 2021, 31, 2391-2397. [CrossRef]

23. Marsden, M.; Weaver, S.S.; Marcu, L.; Campbell, M.J. Intraoperative Mapping of Parathyroid Glands Using Fluorescence Lifetime Imaging. J. Surg. Res. 2021, 265, 42-48. [CrossRef] [PubMed]

24. Mannoh, E.A.; Thomas, G.; Baregamian, N.; Rohde, S.; Solorzano, C.C.; Mahadevan-Jansen, A. Assessing Intraoperative Laser Speckle Contrast Imaging of Parathyroid Glands in Relation to Thyroidectomy Patient Outcomes. Thyroid 2021. [CrossRef] [PubMed]

25. Kennedy, G.T.; Azari, F.S.; Newton, A.D.; Bernstein, E.S.; Fraker, D.L.; Wachtel, H.; Singhal, S. Use of Near-Infrared Molecular Imaging for Localizing Visually Occult Parathyroid Glands in Ectopic Locations. JAMA Otolaryngol. Head Neck Surg. 2021, 147, 669-671. [CrossRef] [PubMed]

26. Wang, Q.; Xiangli, W.; Chen, X.; Zhang, J.; Teng, G.; Cui, X.; Idrees, B.S.; Wei, K. Primary study of identification of parathyroid gland based on laser-induced breakdown spectroscopy. Biomed. Opt. Express 2021, 12, 1999-2014. [CrossRef] [PubMed]

27. Paras, C.; Keller, M.; White, L.; Phay, J.; Mahadevan-Jansen, A. Near-infrared autofluorescence for the detection of parathyroid glands. J. Biomed. Opt. 2011, 16, 067012. [CrossRef]

28. Aoyama, M.; Takizawa, H.; Yamamoto, K.; Inui, T.; Miyamoto, N.; Sakamoto, S.; Kobayashi, T.; Uehara, H.; Tangoku, A. Effects of excitation light intensity on parathyroid autofluorescence with a novel near-infrared fluorescence imaging system: Two surgical case reports. Gland Surg. 2020, 9, 1584-1589. [CrossRef]

29. Akbulut, S.; Erten, O.; Gokceimam, M.; Kim, Y.S.; Krishnamurthy, V.; Heiden, K.; Jin, J.; Siperstein, A.; Berber, E. Intraoperative near-infrared imaging of parathyroid glands: A comparison of first- and second-generation technologies. J. Surg. Oncol. 2021, 123, 866-871. [CrossRef]

30. Kim, D.H.; Kim, S.W.; Kang, P.; Choi, J.; Lee, H.S.; Park, S.Y.; Kim, Y.; Ahn, Y.C.; Lee, K.D. Near-Infrared Autofluorescence Imaging May Reduce Temporary Hypoparathyroidism in Patients Undergoing Total Thyroidectomy and Central Neck Dissection. Thyroid 2021, 31, 1400-1408. [CrossRef]

31. Wiseman, S.M.; Saleh, N.; Tootooni, A.; Eshraghi, P.; Jama, R.; Saleh, S. Parathyroid identification during thyroid and parathyroid operations: A pilot study evaluating a novel low cost autofluorescence based device. Am. J. Surg. 2021, 221, 1150-1158. [CrossRef] [PubMed]

32. Kiernan, C.M.; Thomas, G.; Baregamian, N.; Solomicronrzano, C.C. Initial clinical experiences using the intraoperative probebased parathyroid autofluorescence identification system-PTeye during thyroid and parathyroid procedures. J. Surg. Oncol. 2021, 124, 271-281. [CrossRef] [PubMed]

33. Mannoh, E.A.; Parker, L.B.; Thomas, G.; Solorzano, C.C.; Mahadevan-Jansen, A. Development of an imaging device for label-free parathyroid gland identification and vascularity assessment. J. Biophotonics 2021, 14, e202100008. [CrossRef] [PubMed]

34. Suzuki, T.; Numata, T.; Shibuya, M. Intraoperative photodynamic detection of normal parathyroid glands using 5-aminolevulinic acid. Laryngoscope 2011, 121, 1462-1466. [CrossRef] [PubMed]

35. Jin, H.; Dong, Q.; He, Z.; Fan, J.; Liao, K.; Cui, M. Application of a Fluorescence Imaging System with Indocyanine Green to Protect the Parathyroid Gland Intraoperatively and to Predict Postoperative Parathyroidism. Adv. Ther. 2018, 35, $2167-2175$. [CrossRef] 
36. Orloff, L.A.; Wiseman, S.M.; Bernet, V.J.; Fahey, T.J., 3rd; Shaha, A.R.; Shindo, M.L.; Snyder, S.K.; Stack, B.C., Jr.; Sunwoo, J.B.; Wang, M.B. American Thyroid Association Statement on Postoperative Hypoparathyroidism: Diagnosis, Prevention, and Management in Adults. Thyroid 2018, 28, 830-841. [CrossRef] [PubMed]

37. Delbridge, L.W.; Suliburk, J.; Sidhu, S.; Sywak, M. Parathyroid Cancer: Is There an Epidemic? ANZ J. Surg. 2009, 79, A18. [CrossRef]

38. Park, I.; Rhu, J.; Woo, J.W.; Choi, J.H.; Kim, J.S.; Kim, J.H. Preserving Parathyroid Gland Vasculature to Reduce Post-thyroidectomy Hypocalcemia. World J. Surg. 2016, 40, 1382-1389. [CrossRef]

39. Mihai, R.; Thakker, R.V. Management of Endocrine Disease: Postsurgical hypoparathyroidism: Current treatments and future prospects for parathyroid allotransplantation. Eur. J. Endocrinol. 2021, 184, R165-R175. [CrossRef]

40. Chang, Y.K.; Lang, B.H.H. To identify or not to identify parathyroid glands during total thyroidectomy. Gland Surg. 2017, 6 , S20-S29. [CrossRef]

41. Lang, B.H.; Chan, D.T.; Chow, F.C. Visualizing fewer parathyroid glands may be associated with lower hypoparathyroidism following total thyroidectomy. Langenbecks Arch. Surg. 2016, 401, 231-238. [CrossRef] [PubMed]

42. Antakia, R.; Edafe, O.; Uttley, L.; Balasubramanian, S.P. Effectiveness of preventative and other surgical measures on hypocalcemia following bilateral thyroid surgery: A systematic review and meta-analysis. Thyroid 2015, 25, 95-106. [CrossRef] [PubMed]

43. Lorente-Poch, L.; Sancho, J.; Munoz, J.L.; Gallego-Otaegui, L.; Martinez-Ruiz, C.; Sitges-Serra, A. Failure of fragmented parathyroid gland autotransplantation to prevent permanent hypoparathyroidism after total thyroidectomy. Langenbecks Arch. Surg. 2017, 402, 281-287. [CrossRef]

44. Huang, H.Y.; Li, H.; Lin, S.J.; Deng, W.Y.; Li, Q.L.; Chen, Y.F.; Yang, A.K.; Zhang, Q.; Guo, Z.M. Fine-needle aspiration with measurement of parathyroid hormone levels in thyroidectomy. Zhonghua Er Bi Yan Hou Tou Jing Wai Ke Za Zhi 2013, 48, 934-938. [PubMed]

45. Zou, X.; Shi, L.; Zhu, G.; Zhu, L.; Bao, J.; Fan, J.; Hu, Y.; Zhou, B.; Lv, Z. Fine-needle aspiration with rapid parathyroid hormone assay to identify parathyroid gland in thyroidectomy. Medicine 2020, 99, e19840. [CrossRef]

46. Xia, W.; Zhang, J.; Shen, W.; Zhu, Z.; Yang, Z.; Li, X. A Rapid Intraoperative Parathyroid Hormone Assay Based on the Immune Colloidal Gold Technique for Parathyroid Identification in Thyroid Surgery. Front. Endocrinol. 2020, 11, 594745. [CrossRef] [PubMed]

47. Coan, K.E.; Yen, T.W.F.; Carr, A.A.; Evans, D.B.; Wang, T.S. Confirmation of Parathyroid Tissue: Are Surgeons Aware of New and Novel Techniques? J. Surg. Res. 2020, 246, 139-144. [CrossRef] [PubMed]

48. Grubbs, E.G.; Mittendorf, E.A.; Perrier, N.D.; Lee, J.E. Gamma probe identification of normal parathyroid glands during central neck surgery can facilitate parathyroid preservation. Am. J. Surg. 2008, 196, 931-935, discussion 935-936. [CrossRef]

49. Patel, H.P.; Chadwick, D.R.; Harrison, B.J.; Balasubramanian, S.P. Systematic review of intravenous methylene blue in parathyroid surgery. Br. J. Surg. 2012, 99, 1345-1351. [CrossRef]

50. Solorzano, C.C.; Thomas, G.; Berber, E.; Wang, T.S.; Randolph, G.W.; Duh, Q.Y.; Triponez, F. Current state of intraoperative use of near infrared fluorescence for parathyroid identification and preservation. Surgery 2021, 169, 868-878. [CrossRef]

51. Lavazza, M.; Liu, X.; Wu, C.; Anuwong, A.; Kim, H.Y.; Liu, R.; Randolph, G.W.; Inversini, D.; Boni, L.; Rausei, S.; et al. Indocyanine green-enhanced fluorescence for assessing parathyroid perfusion during thyroidectomy. Gland Surg. 2016, 5, 512-521. [CrossRef]

52. Di Marco, A.N.; Palazzo, F.F. Near-infrared autofluorescence in thyroid and parathyroid surgery. Gland Surg. 2020, 9, S136-S146. [CrossRef]

53. Weng, Y.J.; Jiang, J.; Min, L.; Ai, Q.; Chen, D.B.; Chen, W.C.; Huang, Z.H. Intraoperative near-infrared autofluorescence imaging for hypocalcemia risk reduction after total thyroidectomy: Evidence from a meta-analysis. Head Neck 2021, 43, 2523-2533. [CrossRef]

54. Demarchi, M.S.; Karenovics, W.; Bedat, B.; Triponez, F. Intraoperative Autofluorescence and Indocyanine Green Angiography for the Detection and Preservation of Parathyroid Glands. J. Clin. Med. 2020, 9, 830. [CrossRef] [PubMed]

55. Goncalves, L.N.; van den Hoven, P.; van Schaik, J.; Leeuwenburgh, L.; Hendricks, C.H.F.; Verduijn, P.S.; van der Bogt, K.E.A.; van Rijswijk, C.S.P.; Schepers, A.; Vahrmeijer, A.L.; et al. Perfusion Parameters in Near-Infrared Fluorescence Imaging with Indocyanine Green: A Systematic Review of the Literature. Life 2021, 11, 433. [CrossRef] [PubMed]

56. Dip, F.; Falco, J.; Verna, S.; Prunello, M.; Loccisano, M.; Quadri, P.; White, K.; Rosenthal, R. Randomized Controlled Trial Comparing White Light with Near-Infrared Autofluorescence for Parathyroid Gland Identification During Total Thyroidectomy. J. Am. Coll. Surg. 2019, 228, 744-751. [CrossRef]

57. Thomas, G.; Solorzano, C.C.; Baregamian, N.; Mannoh, E.A.; Gautam, R.; Irlmeier, R.T.; Ye, F.; Nelson, J.A.; Long, S.E.; Gauger, P.G.; et al. Comparing intraoperative parathyroid identification based on surgeon experience versus near infrared autofluorescence detection-A surgeon-blinded multi-centric study. Am. J. Surg. 2021. [CrossRef] [PubMed]

58. Solorzano, C.C.; Thomas, G.; Baregamian, N.; Mahadevan-Jansen, A. Detecting the Near Infrared Autofluorescence of the Human Parathyroid: Hype or Opportunity? Ann. Surg. 2020, 272, 973-985. [CrossRef] [PubMed]

59. Abbaci, M.; De Leeuw, F.; Breuskin, I.; Casiraghi, O.; Lakhdar, A.B.; Ghanem, W.; Laplace-Builhe, C.; Hartl, D. Parathyroid gland management using optical technologies during thyroidectomy or parathyroidectomy: A systematic review. Oral. Oncol. 2018, 87, 186-196. [CrossRef]

60. Wong, A.; Wong, J.C.Y.; Pandey, P.U.; Wiseman, S.M. Novel techniques for intraoperative parathyroid gland identification: A comprehensive review. Expert Rev. Endocrinol. Metab. 2020, 15, 439-457. [CrossRef] 
61. Perigli, G.; Cortesini, C.; Qirici, E.; Boni, D.; Cianchi, F. Clinical benefits of minimally invasive techniques in thyroid surgery. World J. Surg. 2008, 32, 45-50. [CrossRef] [PubMed]

62. Perigli, G.; Qirici, E.; Badii, B.; Kokomani, A.; Staderini, F.; Luconi, M.; Crescioli, C.; Mannelli, M.; Maggi, M.; Cianchi, F. Feasibility and safety of minimal-incision thyroidectomy for Graves' disease: A prospective, single-center study. Head Neck 2013, 35, 1345-1348. [CrossRef] [PubMed]

63. Kim, H.I.; Kim, T.H.; Choe, J.H.; Kim, J.H.; Kim, J.S.; Kim, Y.N.; Kim, H.; Kim, S.W.; Chung, J.H. Surgeon volume and prognosis of patients with advanced papillary thyroid cancer and lateral nodal metastasis. Br. J. Surg. 2018, 105, 270-278. [CrossRef] [PubMed]

64. Onder, C.E.; Kuskonmaz, S.M.; Koc, G.; Firat, S.F.; Omma, T.; Culha, C. Evaluation of management of patients with postoperative permanent hypoparathyroidism. How close are we to the targets? Minerva Endocrinol. 2020. Online ahead of print. [CrossRef] 